Proceedings

\title{
Cultural Changes in the Global Information Age ${ }^{+}$
}

\author{
Huiting Li \\ Department of Philosophy, School of Humanities and Social Sciences, Xi' an Jiaotong University, \\ Xianning West ROAD, No.28, Xi'an 710049, Shaan'xi, China; lhtbisheng@163.com \\ + The Fourth International Conference on Philosophy of Information, Berkeley, California, USA, \\ 2-6 June 2019.
}

Published: 25 May 2020

\begin{abstract}
Cultural changes run through the historical development of human society. Only by having an insight into the cultural changes in the global information age can we grasp the development and future of contemporary culture. Contemporary culture has two major trends of globalization and informatization. This paper focuses on the background of informatization of contemporary culture. Currently, informatization associated with globalization has strengthened the interdependence of national economies, changed the international environment for their development, and enriched their ways of interaction. Under the unprecedented open international environment, the development of any country can no longer be carried out in a closed state. The influence of international public opinion on national development is becoming increasingly important. As a big developing country, China has to communicate with other countries in an allround and multi-channel way so that the world can better understand China and China can create a good international public opinion environment for its own development. This paper will spread out expositions for three aspects: the informatization tide promoted the rise of the information culture industry; the informatization tide intensifies the cultural interaction and competition among countries; the informatization tide enriches cultural communication among countries.
\end{abstract}

Keywords: informatization; cultural industry; cultural communication

\section{Introduction}

Whether synchronic culture or diachronic culture, culture is essentially evolutive and dynamic. Change is the inherent regularity of culture. From the perspective of the internal evolution of culture, the subject is directly or indirectly stimulated and catalyzed by information in social practice, so as to recombine and construct the original cultural factors and heterogeneous cultural factors, and finally form the cultural change. The progress of human civilization is attributed to the repeated and spiral cultural changes, that is, continuous heterogeneous isomorphism and catalytic recombination.

Reviewing the history of the world culture, cultural development can be attributed to the innovative ideas and inventions of wise men, though the transportation was undeveloped and the information was not circulated. Compared with ancient times, cultural changes in modern and contemporary times are often influenced by external factors and driven by information. The "soft" [1] power of culture transcends economic, political, and military power and is deeply integrated into the vitality, creativity, and cohesion of the nation. Actually, the attraction of a nation is its culture. In the era of globalization, informatization promotes cultural communication and conflicts. The power of culture is amplified by information technology, which has expanded the country's economic, political, and military power in the international community, thus becoming an indispensable and important part of the comprehensive national strength [2]. 


\section{Informatization Promoted the Rise of Information Culture Industry}

Under the global revolution flow of science and technology, cultural industry can be transformed and upgraded by adopting modern high-tech [3]. It is the most important means of promoting cultural and technological innovation.

As an artist and a scientist, Leonardo Da Vinci presented us that "Art can fly high only with the help of the wings of science and technology" [4]. Every technological revolution presents an opportunity for the developing world. As the most developed developing country in the world, China cannot afford to miss this opportunity. Represented by digitalization, Network and MultiMedia, the contemporary information revolution has not only brought a new economic form - digital economy and network economy - but also brought a new cultural form-digital culture and network culture. At present, China's information industry is developed vigorously. It has become the most significant industry of national economic and social development. However, the cultural industry begins as a weak industry. According to the industry analysis, the contemporary information revolution has gone through the transformation process from hardware to software, and is moving from the era of network to the era of content. Only when Internet industry and content industry merge and develop can the information industry have a promising future. In this sense, the contemporary information industry is no longer a pure information technology industry, but a unification of the information technology industry and information culture industry. Similarly, only by combining the cultural industry with the information industry, making industrialization and informatization mutually reinforcing, and taking the road of new industrialization, will it be possible to achieve extraordinary leap-forward development [5]. The rise of the information culture industry is one of the most prominent symbols of the contemporary information revolution. It is an inevitable choice for the development of China's cultural industry to spread advanced culture with advanced science and high technology, constantly improve the contribution rate of science and technology to culture, and thus realize the harmonious development of high technology and advanced culture.

The development of culture in today's world has attracted attention. The wide application of high and new science and technology in the field of culture has created numerous novel cultural forms, opened up vast unfamiliar territory for the traditional cultural map, and promoted the continuous progress of human civilization to a higher realm and reached a further border. As we know, most cultural products are content products with inherent virtual characteristics, and are considered to be best suited for online production, circulation, and consumption. These cultural products can complete the whole process of production, transaction, and consumption on the Internet. Therefore, the online cultural market has become one of the markets that most conforms to the nature of the online world.

\section{Informatization Intensifies the Cultural Interaction and Competition among Countries}

The wave of informatization has changed the international environment for the development of various countries and intensified the cultural interaction and competition among them. In today's world, science and technology are changing with each passing day. The information technology represented by digital technology, network technology, and multimedia technology is bringing us into a brand-new information age [2]. In the 1980s, we were still amazed by the information explosion, and the new scientific and technological revolution built the information superhighway in front of us. As everyone feels, we are unmistakably in it. The rapid development of digital technology and multimedia technology and the wide application of the Internet have revolutionized the scope, speed, and form of information dissemination and brought the contemporary information revolution to a higher level. Its powerful power of transmission, communication, and sharing of information enables human beings to break through the limitations of time and space. This sudden information age makes our planet become so small, just like a village where the sound of chickens and dogs can be heard. Outside the global village, there is no paradise. In this case, no country can stand aside, and no country cannot participate in the interaction and competition involuntarily. Either my culture influences you, or your culture influences me. 


\section{Informatization Enriches the Cultural Communication among Countries}

Before the information age, the communication and exchange between different national cultures were limited and slow. After entering the information age, information technology provided the technical conditions and means for communication between different national cultures, which expanded the breadth and depth of the world and accelerated the communication between different cultures. In this case, between countries, between national and ethnic culture competition, full of vitality, creativity, and cohesion, the spread of culture will shine, foreign produce great assimilatory power and influence, and to extend the influence to the interests of the state level, which in the form of a kind of culture to enhance the comprehensive strength of the country. That is to say, the wave of information technology has enriched the ways of cultural communication among countries, deepened the breadth and depth of cultural interaction among countries, and provided a way and platform for the vigorous display of cultural power.

\section{Conclusions}

Information technology, which is developing vigorously, has a broad and profound impact on the mode of production, way of life, and way of thinking of human beings, on the way of cultural communication and interaction among countries, and on all fields and levels of social life, including cultural life. In other words, in the information age, the ontological form, economic form, technical form, functional form, and communication form of culture are changing. The major task of the states and nation is to grasp the pulse of The Times, conform to the trend of high-tech development, and promote the prosperity and innovation of the national culture.

\section{References}

1. Wu, K. Philosophy of Information: Theory, Method and System; The Commercial Press: Beijing, China, 2005; pp. 266-275.

2. $\mathrm{Wu}, \mathrm{K}$. Constructional Propositions of Unified Complex Information System Theory. Stud. Dialectics Nat. 2006, 6, 96-99.

3. Huntington, S.P. The Clash of Civilization and the Remaking of World Order; Simon \& Schuster: New York, NY, USA, 1998; pp. 177-198.

4. Van Peursen, C.A. The Strategy of Culture: A View of the Changes Taking Place in Our Ways of Thinking and Living Today; China Social Sciences Press: Beijing, China, 1992; pp. 89-124.

5. Tomlinson, J. Globalization and Culture; University of Chicago Press: Chicago, IL, USA, 1999; pp. 47-99.

(C) 2020 by the authors. Licensee MDPI, Basel, Switzerland. This article is an open access article distributed under the terms and conditions of the Creative Commons Attribution (CC BY) license (http://creativecommons.org/licenses/by/4.0/). 